mosome and the double helix, 3 the codon, 4 the canonical nucleotides and 5 the pentagonal faces in an icosahedral virus. Brenner's luminous insights repeatedly bring you up short as you read. There is also here a certain nostalgia for a glorious past, when the problems of molecular biology yielded to cogitation and to discussion in the coffee room, and not merely to a brutal experimental assault.

In those days theory was king, and Niels Bohr's principle that one should never believe an experiment that was not confirmed by theory held sway. Occam's razor was complemented by Brenner's noble conceit of Occam's broom, which was used to sweep out of sight the more inconvenient facts. Today's technology allows important facets of nature to be brought to light at such a rate that, says Brenner, "pausing to think about the results, or asking how cells really work, is likely to be seen as a source of irritating delay to the managerial classes, and could even endanger the career of the questioner".

He deplores also the advent of researchby-kit, for we seem indeed to be heading for a future in which not only the sequencing of DNA and the production of antibodies, but also the identification of new genes and their products and in due course the very formulation of the questions themselves, will be farmed out to commercial organizations for money. And then perhaps the bureaucrats will suddenly find Utopia within their grasp, because the uncouth and refractory scientists will no longer be needed.

Brenner is dismayed by the relentless advance of bureaucracy in general. We have entered an age of strategic mission statements and management training courses. (The UK Medical Research Council actually offers courses in how to appraise and discipline technicians, though of course they are not called that now.) Security is another of his bugbears, although he does not mention safety, which is now the prime growth area in many organizations. To my mind, much the most dangerous place in most laboratories is the only one the safety officer habitually spares - the library, with its ever-present hazard that a bound volume of the J. Biol. Chem. will fall from a high shelf and make an end of you.

If, then, you are not the person who has razored out the last page of Current Biology and you want a guide to how to comport yourself in your scientific career and to survive and even thrive, then I urge you, for your pleasure and profit, to buy Uncle Syd's book. You may possibly (especially if you are one of the campfollowers of the profession) want to gratify him with the abusive letters and obscene telephone calls of which he has so far been disappointed. As the old bruiser Kingsley Amis once observed: "If you can't annoy somebody with what you write I think there is little point in writing."

Walter Gratzer is at the Randall Institute, King's

College London, London WC2B 5RL, UK.

\section{Life's dead letter}

\section{Lifelines: Biology, Freedom,} Determination

by Steven Rose

Allen Lane: 1997. Pp. 335. £20. To be

published in the United States by Oxford

University Press in January at \$30

\section{Benno Müller-Hill}

Genetics has been one of the most successful sciences of the twentieth century. Yet its history is not a simple success story. In the Soviet Union, genetics was almost destroyed. In Germany, it served as an argument for mass murder. In the United States, it was used to legitimize mass sterilization, laws against racial mixing and a restrictive immigration policy.

And today, a sizeable minority of the public looks at developments in genetics with disrespect.

Steven Rose is a biologist who has claimed in many books that something is deeply wrong with biology itself. In his latest offering, he suspects that the culprits are reductionism and biological determinism. He writes: "The challenge of the opponents of biological determinism is that, while we may have been effective in our critique of its reductionist claims, we have failed to offer a coherent alternative framework within which to interpret living processes... Lifelines originated as an attempt to meet the challenge."

Rose begins by presenting a brief history of biology and genetics. In a discussion of T. H. Morgan's work on mutant fruitflies, he writes that "they had red rather than white eyes". It was in fact the other way around! $\mathrm{He}$ then points out that "the proportion of unusual characters in the fly population could be greatly increased by stressing it in some way - for instance by exposing the flies to not-quite toxic concentrations of particular chemicals, or to radiation such as X-rays". It was H. J. Muller, not Morgan, who discovered the mutagenic action of X-rays. The reader will be confused by Rose's account of history.

One of Rose's central points is that genetics, which deals with single genes and gene products, is unable to illuminate the processes of development and evolution: "The great expansion of genetic knowledge in recent decades has yet to be matched by a comparable increase in the understanding of development."

He neglects to mention the work of Ed Lewis or Christiane Nüsslein-Volhard and their colleagues. In fruitflies, the first stages of development are now well understood, and in fish we may know them soon.

It is true that mouse and human development are still mysteries. But these mysteries are challenges to geneticists. Rose sees it dif- ferently: "Reductionist ideology has a number of serious consequences. It hinders us biologists from thinking adequately about the phenomena we wish to understand." I think he is wrong, and I hope he is unsuccessful in selling his idea to young biologists who might read this book.

Rose then sets out to attack the 'ultraDarwinists' Daniel Dennett and Richard Dawkins. Again, I think Rose's point is badly taken. "To isolate from this evolving web a single factor, be it a gene or organism, as the unique determinant of change is as problematic as isolating a single enzyme from the metabolic web that constitutes the cell. Any such attempt at isolation is a reductionism that mistakes method for theory." I and many others have put some effort into isolating such genes and I remain convinced that the results of our studies have better illuminated our understanding of the living cell.

After warning his readers against the dangerously seductive character of metaphors, Rose presents us with those of his own choice.

Here is a selection: "We must speak of the dialectic of specificity and plasticity during development, the dialectic through which the living organism constructs itself"; "...to offer a perspective on biology which transcends genetic reductionism, by placing the organism, rather than the gene at the centre of life - this perspective I call homeodynamic"; "Our lives form a developmental trajectory, or lifeline, stabilised by the operation of homeodynamic principles. This trajectory is not determined by our genes, nor partitioned into neatly dichotomous categories called nature and nurture. Rather it is an autopoietic process". These quotations give the flavour of what is to replace reductionism if we follow Rose.

So we come to what seems to me the central issue. Rose argues that "the argument against hunting for neurogenetic explanations (for violence etc.) is not that it is immoral or unethical to do so. It is simply that, despite the seductive power of reductionism it is the wrong level of the disciplinary pyramid". To my mind, violent crime is not part of science. If it is made part of genetics, it converts genetics into an ideology or religion, as has been demonstrated in Nazi Germany.

Finally, Rose sets about "making Biology whole again" by delivering, as a new Moses of biology, "biology's Decalogue". As far as I could tell, it bears no resemblance whatsoever to the old Decalogue. To quote its last sentence: "And it is therefore our biology that makes us free."

If I had to choose, I'd prefer the Mosaic version.

Benno Müller-Hill is at the Institute of

Genetics, University of Cologne, Cologne 50931,

Germany. 